\title{
Study on Urban Sustainable Restructuring of Leinefelde, Germany and Revealing the Important Strategies for Environmental Well-Being for Shrinking Cities
}

\author{
Sri Charan P \\ Assistant Professor, Faculty of Architecture, \\ Manipal Academy of higher education, India
}

\section{Abstract}

Why habitat Mars when you can make earth livable. Demographic change led to the shrinking of the city and also aging native population were big problems in leinefelde. Sustainable urban structures, housing affordability and availability was a big criteria. The political and economic change in the eastern Germany after reunification in 1989, anticipated and intensified the problems. By 1993 municipality realized that it should develop strategies and policies to stop the breakdown of economic and political breakdown of the city. As a result of the actions taken, leinefelde has become successful transformation of shrinking cities in the world. This research paper finds the problems led to shrinking of the city and then focuses on the different parameters and strategies like project context, social aspects, environmental aspects, economic aspects, organizational aspects, sustainable aspects that were carried out in order to have a successful transformation of leinefelde. And finally list down the key indicator for project being successful as a conclusion.

Keywords: Restructuring, project context, social characteristics, environmental features, economic aspects, organizational aspects, sustainable and innovation.

\section{Introduction}

Until 1960s leinefelde was a small village in the rural eichsfeld region. The division after World War II led the village separated from its traditional markets and West Germany economy. Subsequently, in 1960 East Germany government began a large industrialization for the region "Eichsfeld Plan". Which led to the village from 2500 habitants to 16500 modern industrial town. In corresponding to the construction of textile industries in leinefelde, a new town was developed - Sudstadt. Sudstadt town was designed to the predominant ideal socialist town: blocks of pre-fabricated flats set in a green landscape, sports fields and infrastructure facilities. In 1969, Leinefelde was given an eminence of an urban municipality, with responsibilities and rights of East Germany's 
German democratic republic (GDR). After twenty years, the reunification of Germany gave leinefelde status as urban municipality and in 1990 municipal council and mayor were elected in the first free vote after the world war[1].

In 1993, lot of local population was leaving leinefelde to find the fortune somewhere else. The main reason is because of the reunification of Germany led to change from an organized to a market economy, this in general has changed the value system and socialist housing policy. The main reason is the lack of sustainability, soon it became evident and downfall of textile branch after reunification destroyed the economics of the town. This led to the growing unemployment rates in the city and many people left to the most prosperous regions in Germany which led to the vacant flats. And in the competitive housing market, standardized pre-fabricated units with low quality were rejected which were the major housing units. People who are better off moved out from the apartments and owned their new houses. This directed to the depopulation of leinefelde and sudstadt, native population is decreasing and aging population added more to collapse of the city.

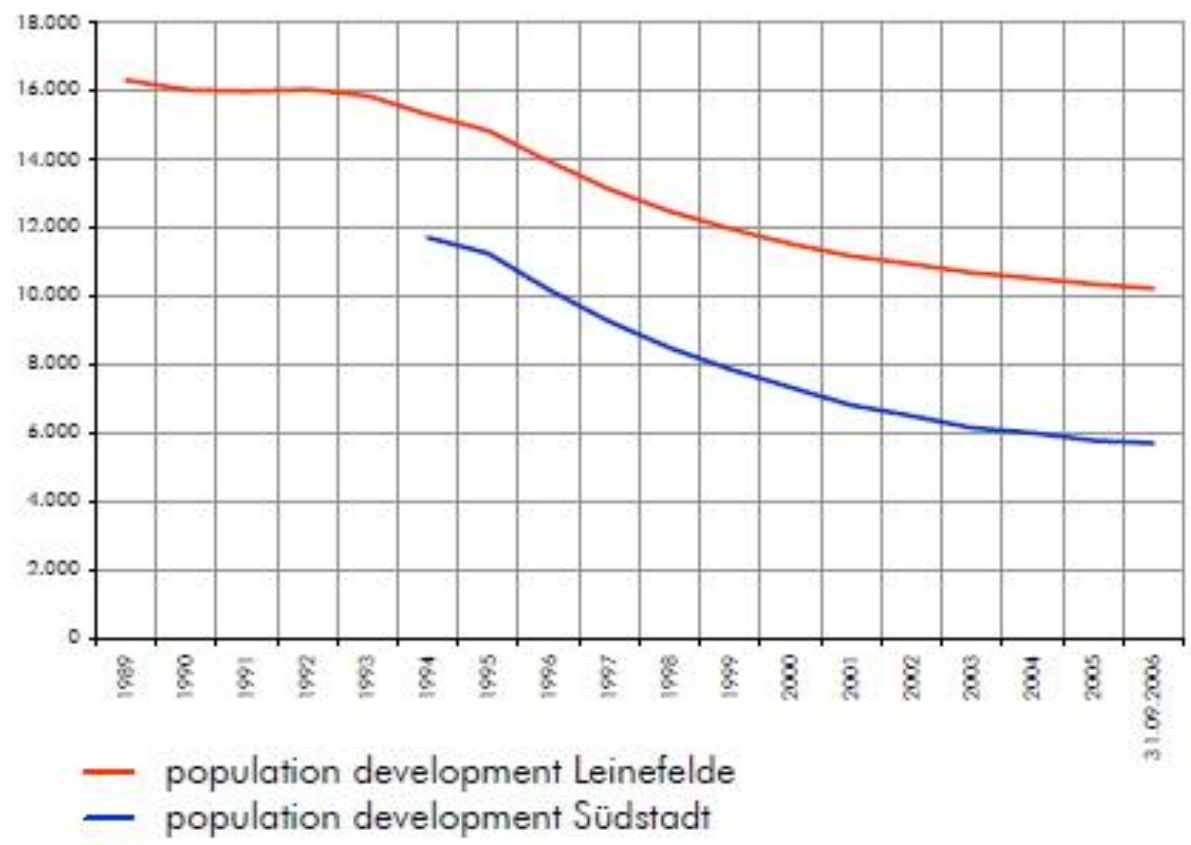

\section{Graph 1: Depopulation in leinefelde and sudstadt}

By analyzing the graph it is evident that the demand for rental property in the city was decreased by 50 percent.

But 1993, Mayor and administration took the following first steps towards sustainable urban development of the city: 
- Subsidy program run cooperatively by the German federal government and the state of Thuringia.

- Authorizing an urban development master-plan in order to explore the potentials of the sudstadt district.

- Implementing an initial pilot project "the refurbishment of boniftius square"Public open square.

- Municipality with its responsibility for urban and social enhancements had been involved in number of actions, Such as:

- Establishing a participative development process.

- Encouraging economic development.

- Public subsidies for transformation processes.

- Commencing quality and quarter management.

- Renewing flats.

- Renovating all social and technical infrastructures under public responsibilities.

\section{Main Aims and Strategies of the Project:[1][2]}

- Maintaining balance between employment capacities, number of habitants, urban structures and housing volumes.

- Improving surroundings, environment and living conditions.

- Promote affordable and attractive housing.

- Progress social, economic and community life in the city.

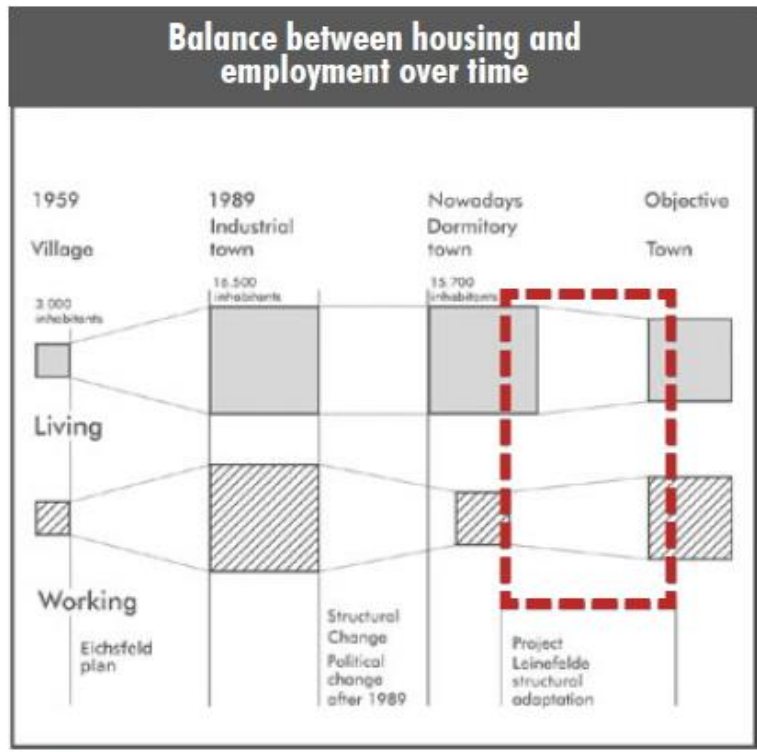

Hane project timeframe

Fig 1: Balance between housing and employment over time. 
The above mentioned aims were achieved by following strategies:

- Sustainability through contribution.

- Sustainability from employment and a diversified economy.

- Sustainability through energy conservation and recycling of building materials.

- The master plan as an apparatus of direction.

- High excellence public amenities and infrastructure to make town attractive.

- Demolition of empty apartment building to offer new urban potentials and market steadiness.

- Improvement of the housing surroundings.

- Making difference between private and public space to have "ownership".

- Different housing typologies as a means of social amalgamation.

\subsection{Sustainability through contribution}

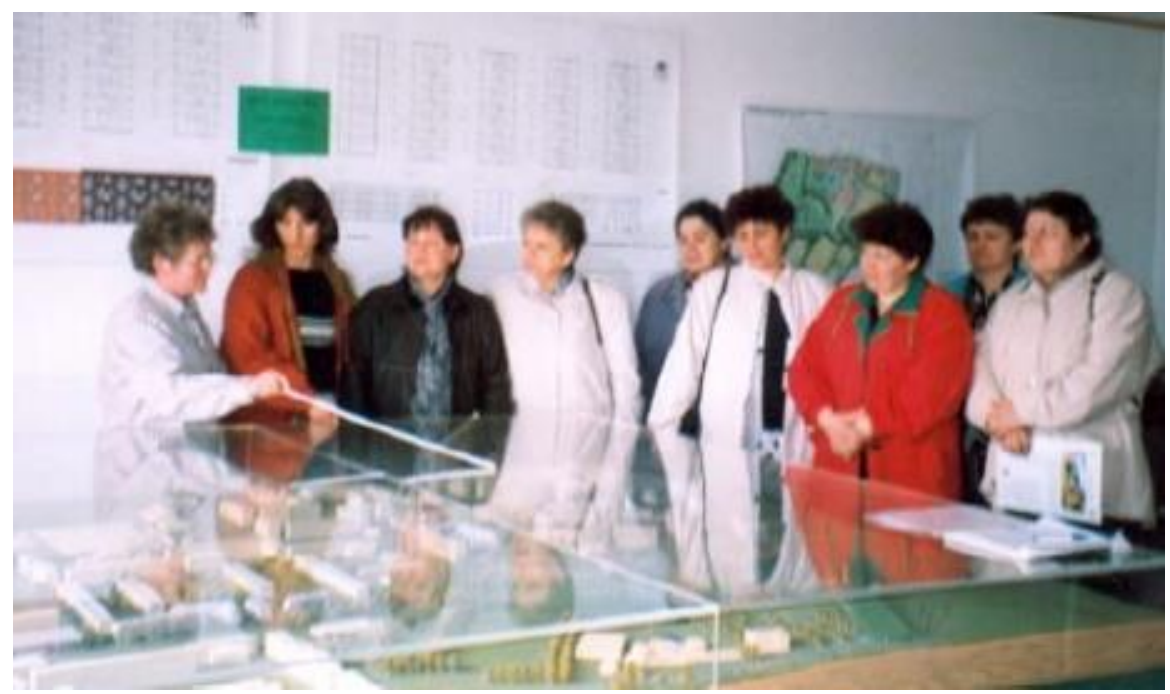

Photo 1: Communal participation in the project

Main idea for all the activities to be based on coordination between stakeholders and the target groups in order to promote ownership. Active local participatory is important for establishing sustainable investment in housing renovation. 


\subsection{Sustainability from employment and a diversified economy}

Economic structure of Leinefelde compaired to region and country (2005)

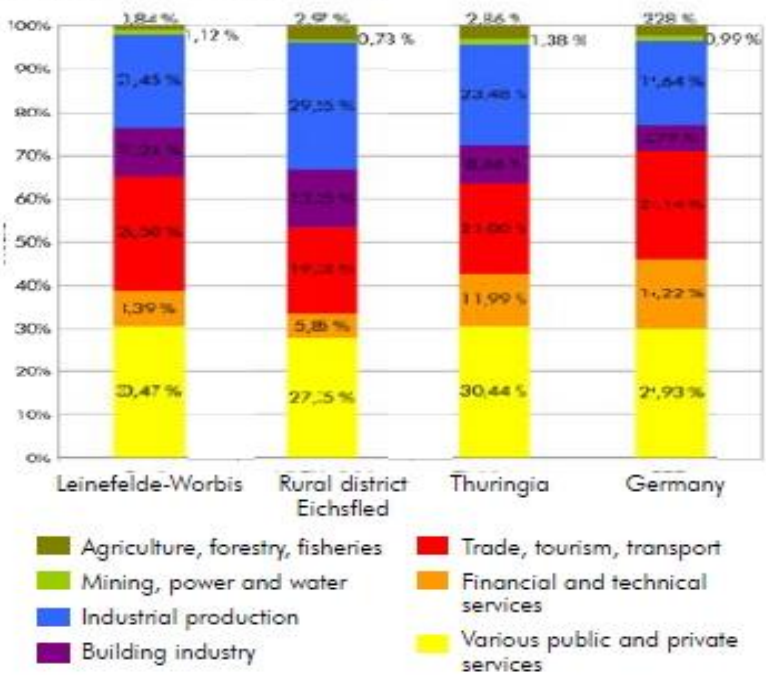

\section{Graph 2: Economic structure of Leinefelde}

The reason for unemployment and migration in the city was because due to onedimensional structure of the economy. To solve this, the municipality promoted the establishment of new enterprises with a different range of activities. Empty textile factory was converted into accommodation facilities, newly designed industrial area and trading estates provided complementary opportunities.

\subsection{Sustainability through energy conservation and recycling of building materials}

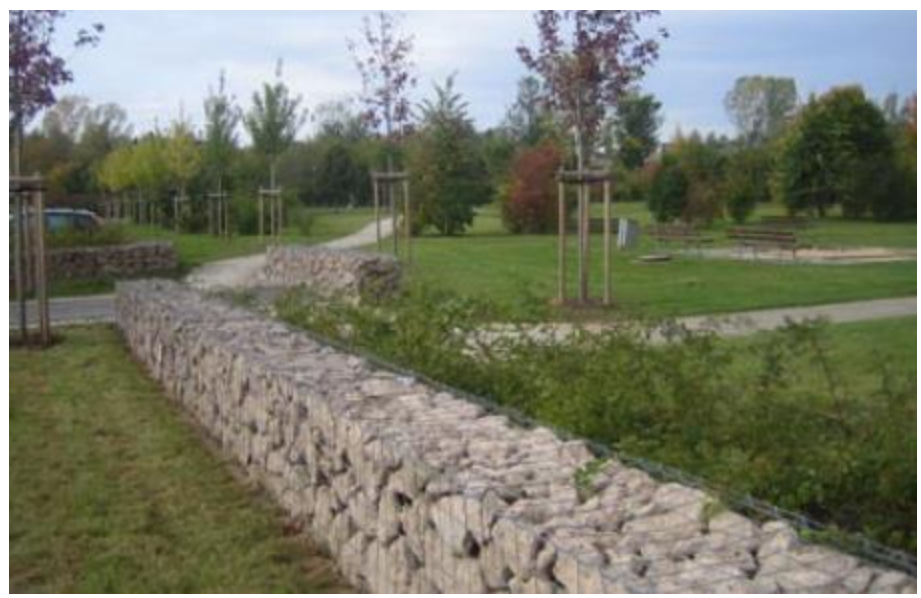

Photo 2: Recycling and reuse. 
The demolition and the dismantling of prefabricated concrete slab construction from housing units helped to procure the transformation process with raw materials which are reused both in construction and landscaping. As a result, it reduced transportation and dumping cost. Interesting landscaped almost free of cost.

\subsection{The master plan as an apparatus of direction}

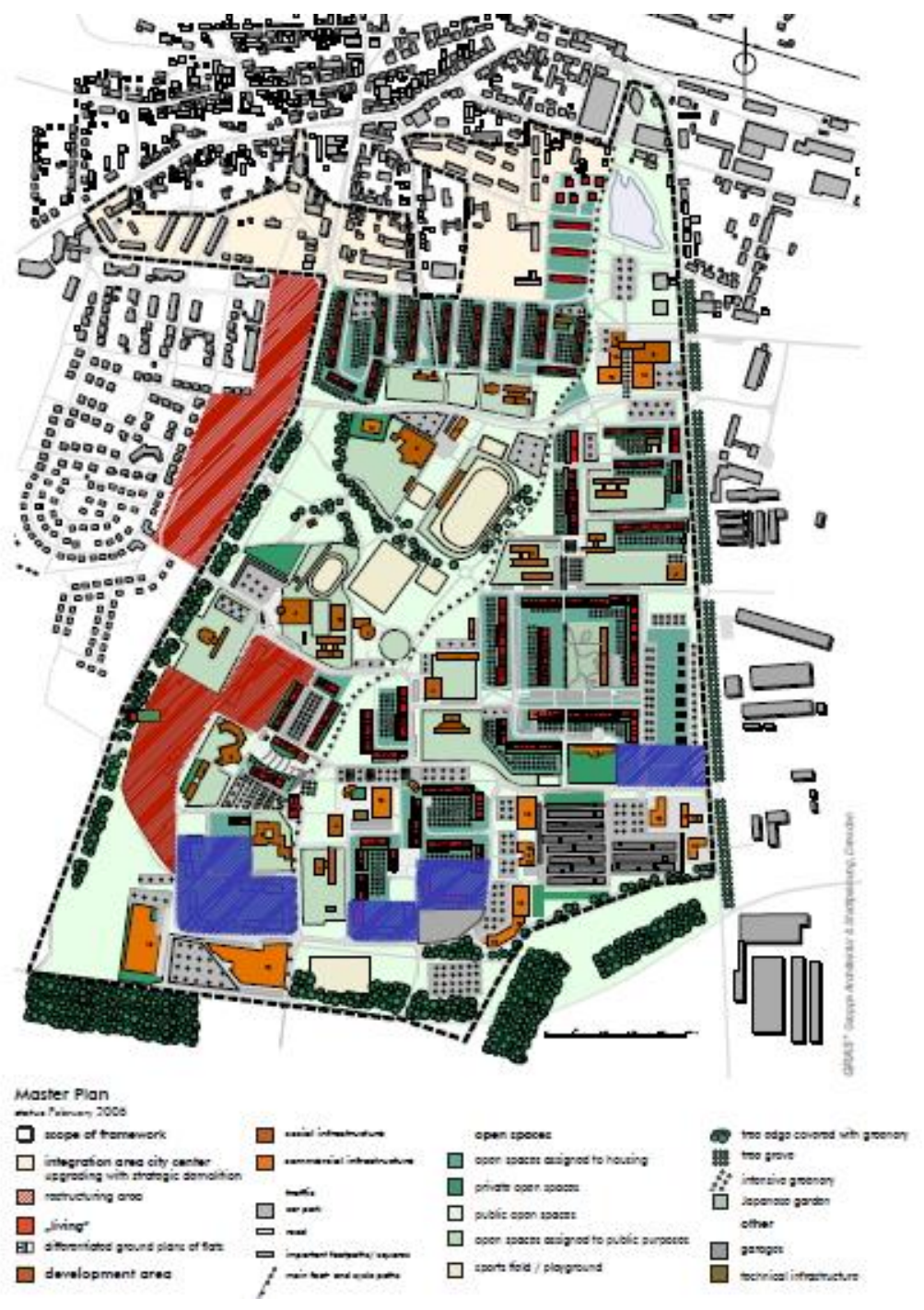

\section{Photo 3: Master plan of leinefelde}

First stage of the project included master plan drawn and agreed in 1995. It basically established guidelines for renewal and in particular to the core area. Master plan is a result of discussion between stakeholders. 


\subsection{High excellence public amenities and infrastructure to make town attractive}

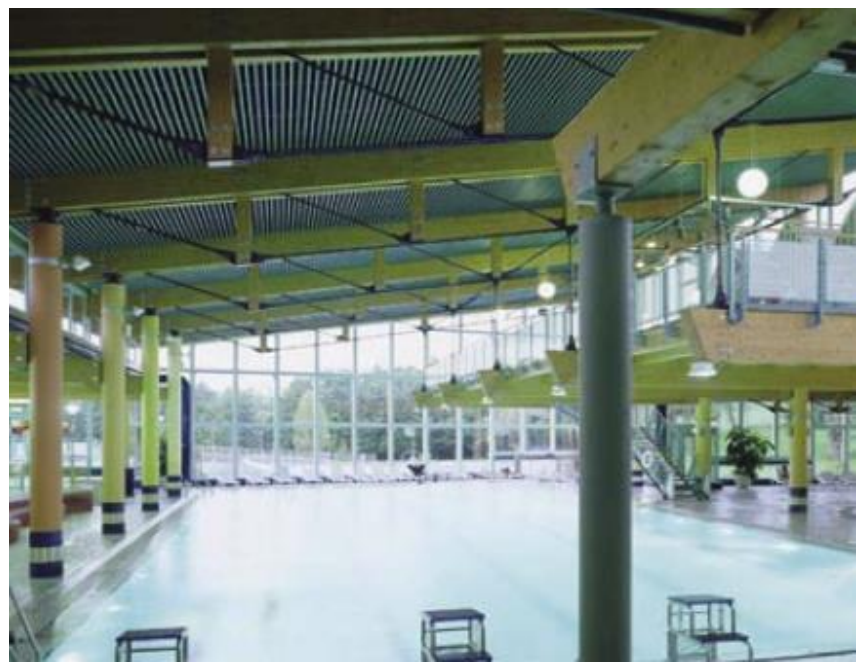

\section{Photo 4: New swimming pool}

To stop the outward migration, municipality with partners offered high quality facilities and infrastructure like new swimming pool, kindergartens and public transport system. Public investment is for communal good and also provide sustainable private investment in the city.

2.6 Demolition of empty apartment building to offer new urban potentials and market steadiness [3]

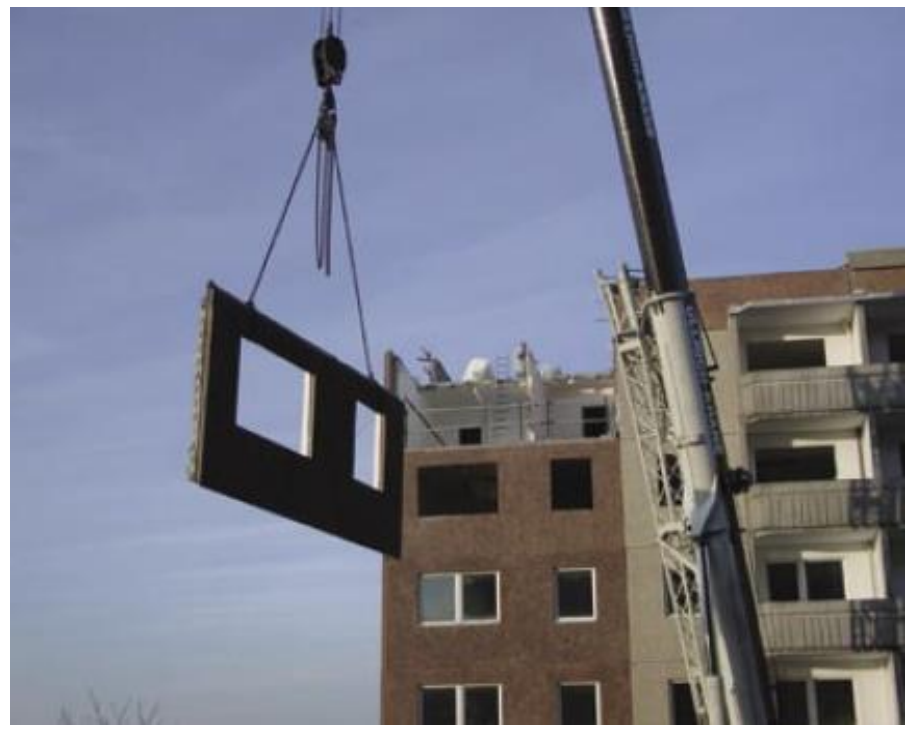

Photo 5: Dismantling of prefabricated houses. 
It was decided that $50 \%$ of the existing housing will be demolished and the remaining renovated in order to improve urban quality and to have healthy housing market. Reducing density, improving and opening urban spaces will revitalize the core area.

\subsection{Improvement of the housing surroundings}

The project ensured different types of open spaces for private, semi private and public use. Variety of flora and fauna in open spaces improve the ecology of the surroundings. Parking, courtyards and accessibility were designed for easement.

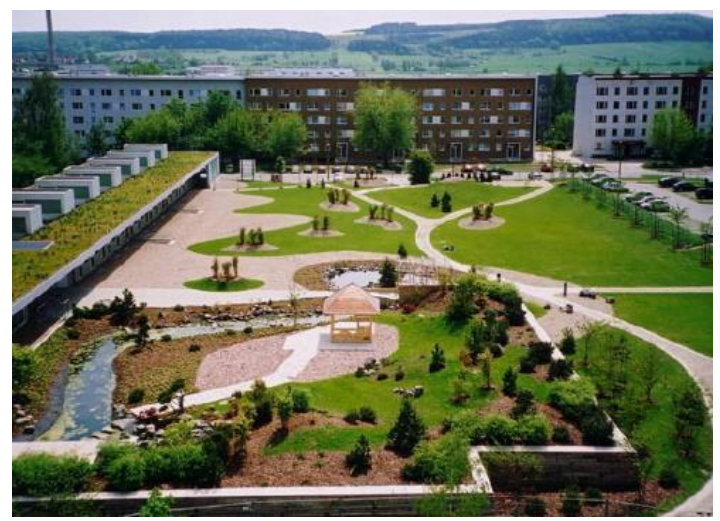

Photo 6: Urban landscape near housing.

2.8 Making difference between private and public space to have "ownership"
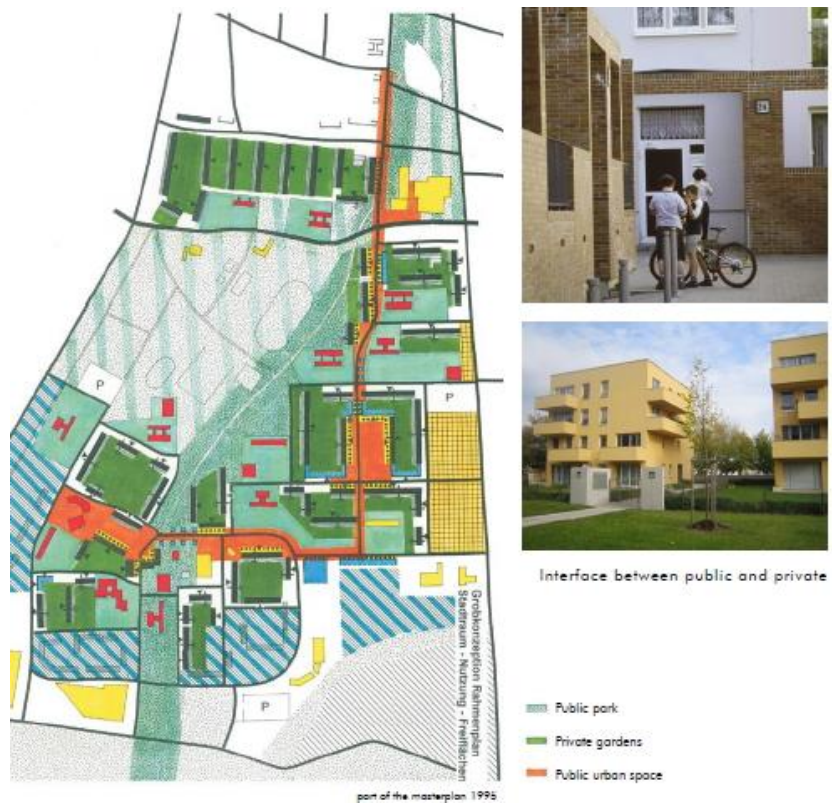

Interface between public and private

In Public pork

- Privere gardens

- Public urbon spoce

Photo 7: Private, semi private and public space. 
A very clear divisions were made between private, semi private and public spaces. Giving spatial transition when accessing different spaces. Special importance to the public squares as it is more intensifies public life and civic individuality.

\subsection{Different housing typologies as a means of social amalgamation}

City had different social categories with a features in socialist housing schemes. To preserve the mixture in a market economy, a variety of housing typologies were designed and constructed. Renovation projects aimed at individualize flats, building and housing area.

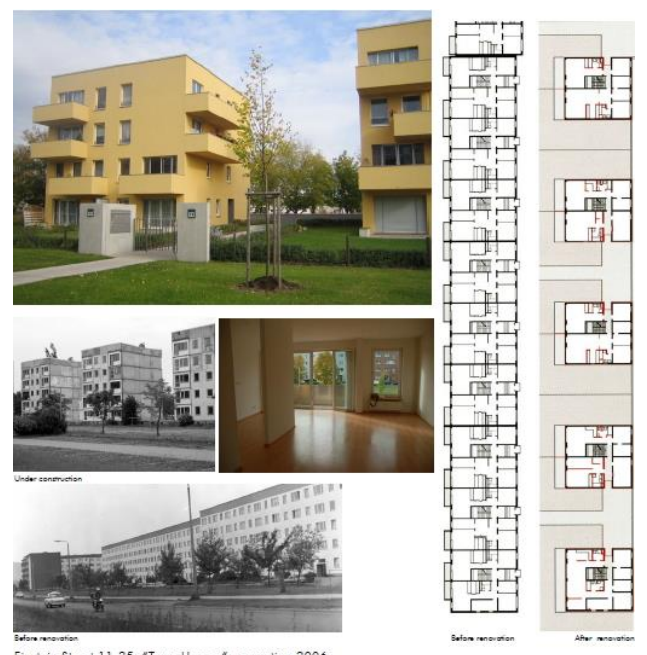

\section{Photo 8: Successful reconstruction of apartments.}
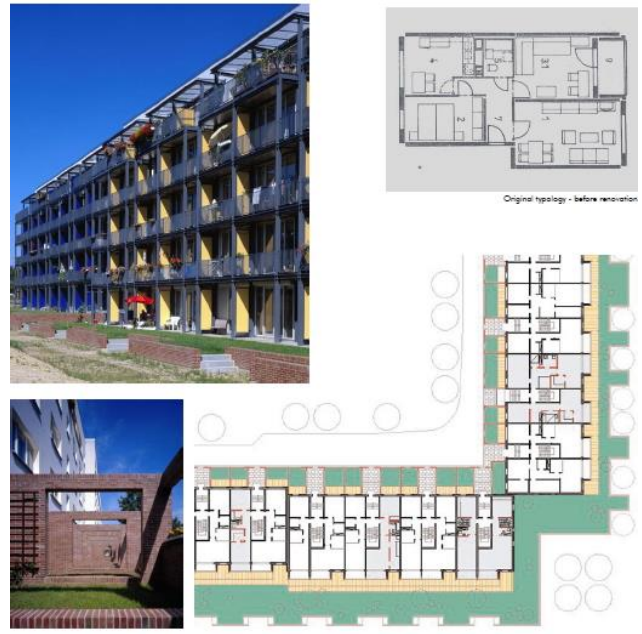

Lessing Street renovation $1999-2001$

Photo 9: Successful renovation of apartments. 


\section{Financial Aspect}

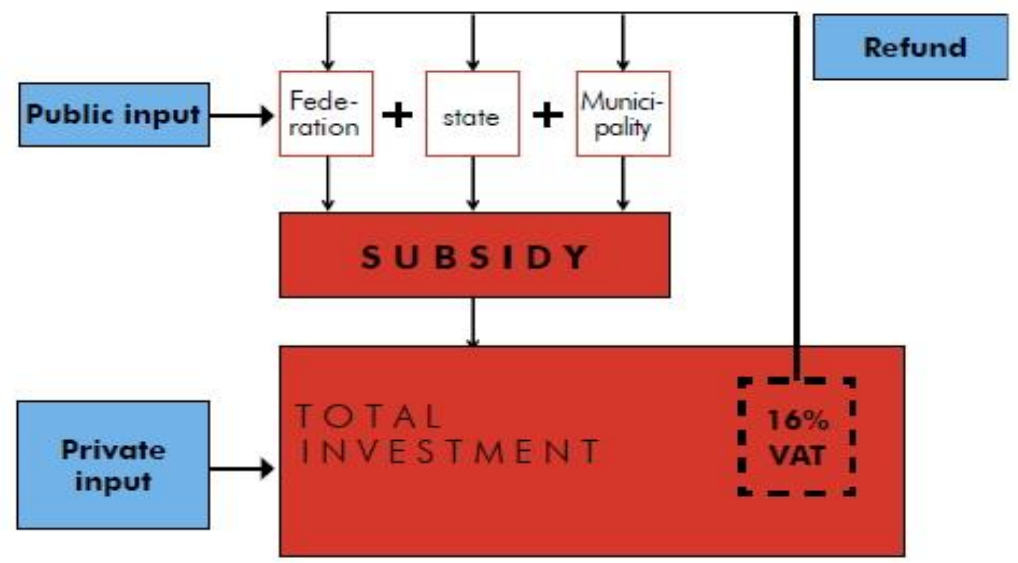

\section{Flow Chart 1: All the aspects of finances for the project. [1]}

The project financed according to the renovation and renewal of the following facilities: Housing renovation generally offer finance with interest rates to cover nonprofit yielding expenditure.

Urban renewal is mainly to target public facilities. The municipality bears almost 25 to $30 \%$ of the cost.

In 2002, a new program was offered that aims to associate market by financing the demolition of vacant flats. $100 \%$ subsidy in case of simple demolition.

Since 1993, a total of 140 million euros has been invested in refurbishment, new construction and private green space.

Average investment for renovation varies from 470 euro/meter square to 820 euros, which is still less than the half of the construction of new building. 


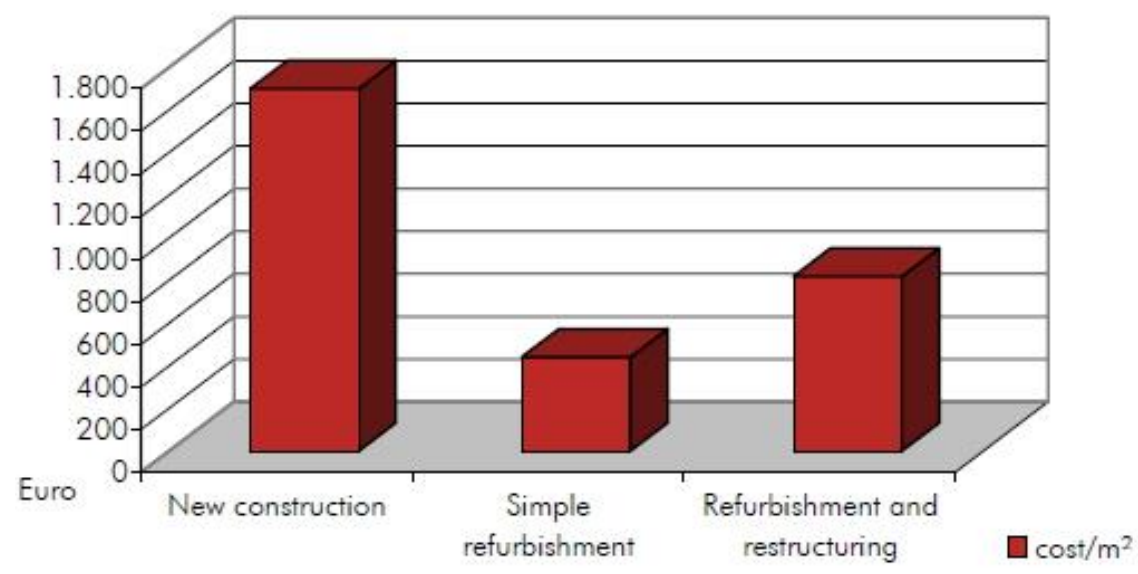

Specific refurbishment cost

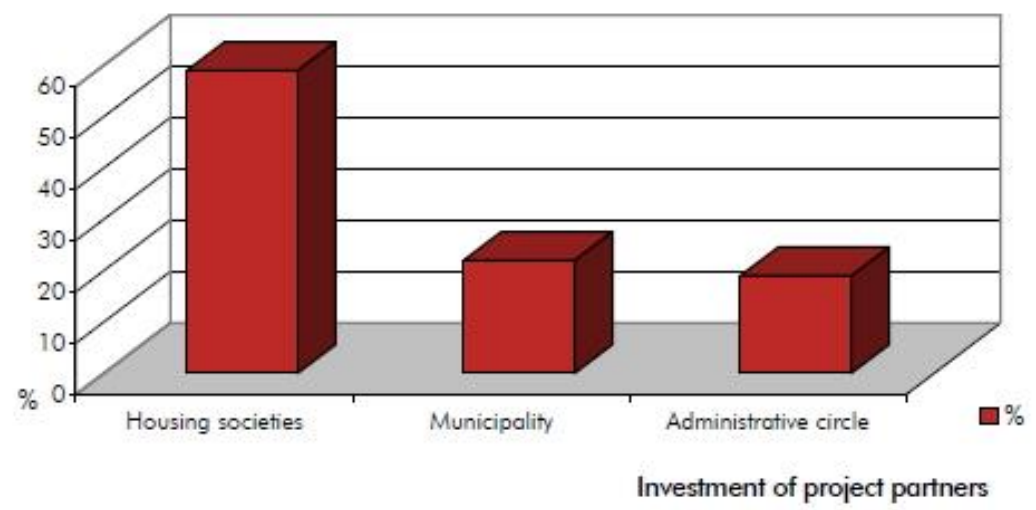

Graph 3: Cost per square meter and investment of project partners.

\section{Social Aspects [1][6]}

The integrated approach helped develop employment opportunities and town with great levels of urban quality. This allowed inhabitants to develop social and physical environment. The following have proven for encouraging social sustainability and community empowerment:

Discussions between municipality, landlords and tenants.

Survey on residents for their current state and their hopes and expectations.

A regular newspaper for the updates.

Workshops for particular project for tenants and stake holders. 
Social service center offers assistance to problem groups.

Different standards of renovation: no exclusion for low or high income group.

\section{Environmental aspects [1]}

To improve environmental quality is important factor for sustainability and helped in the transformation process in leinefelde and the principles followed are as follows:

Diversity and intensity by planting different local species of trees and vegetation.

Established biological links and micro climatic exchanges in landscape areas.

Improvement of the energy efficiency of buildings by modern heating, technologies and renewable fuel.

The reuse of concrete slabs and pieces for landscape architecture and allow of entire concrete slabs for the construction of detached houses.

Reconstitution of ground water is important for sustainable bio diversity.

Improving pedestrian areas and cycle paths.

\section{Organizational aspects}

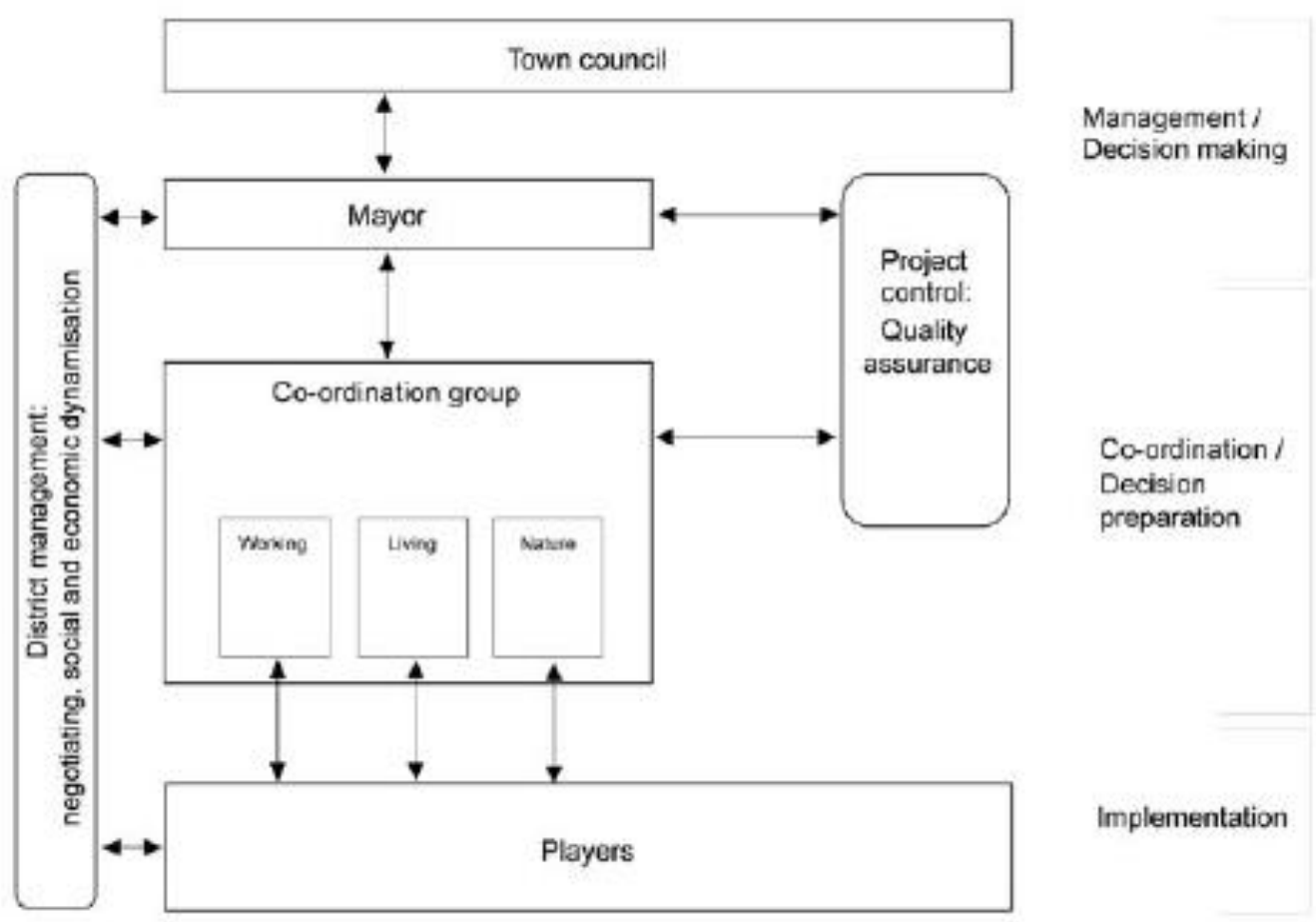

Flow Chart 2: Organizational chart for entire project 
Organizational setup of the project places all the different stakeholders under common leader. The key factor is the balance between individuals, common interests and project decisions.

Regular meetings, guarantee coordination and quality management is necessary for the whole transformation process. District management provides link between habitats and the project. It collects and distributes information both direction. It works actively to improve social situations of long term unemployment, lack of qualification and family troubles. From the start, municipality engaged an external consultant for strategic planning, coordination and quality management. The consultant closely works with mayor and head of the urban development.

\section{Monitoring and evaluating [5]}

The project was regularly monitored using global indicators: demographic data, urban development, housing supply \& demand and the financial \& economic situation. These data could be used for the adjustments of the master plan. Two surveys (1994 and 2001) analyzed inhabitant's responses to the project. It confirmed the fundamental change in social attitude, perception of quality.

\section{Conclusion}

Key indicators of the projects success are conclusion and are as follows [7]:

Demographic and social development: demographic erosion has been slowed and 150 inhabitants are lost per year.

Urban development: 1764 apartments have been demolished, 4 years ahead of the project initial schedule, thus anticipating the future reduction in subsides.

Economic development: There are currently 1200 businesses in the city and the regional unemployment rate in 2005 was $15 \%$ significantly lower than the state of Thuringia average of $18 \% .1300$ people commute to city for employment opportunities.

Financial situation of municipality: Leinefeldes's municipality debt is 650 euros per inhabitant despite its below average per capita tax income, which is lower than the average in state of Thuringia i.e. 960 euros per inhabitant. 


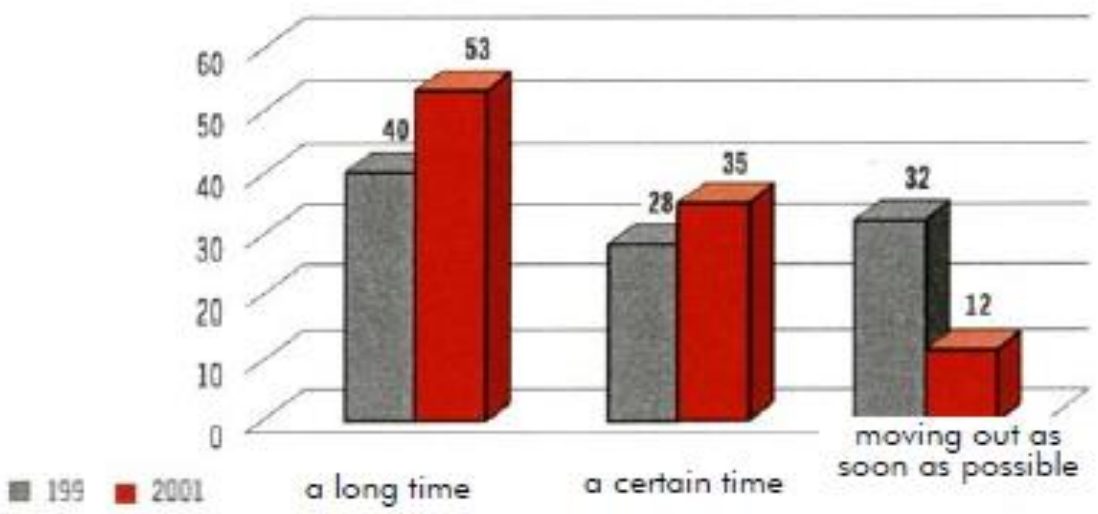

public-opinion poll: "How long will you stay in Südstadt Leinefelde?"

building / buying a house relocating a new job dislike of housing environment apartment is too expensive apartment is too small apartment is too big dislike of the apartment dislike to the social environment family reasons other

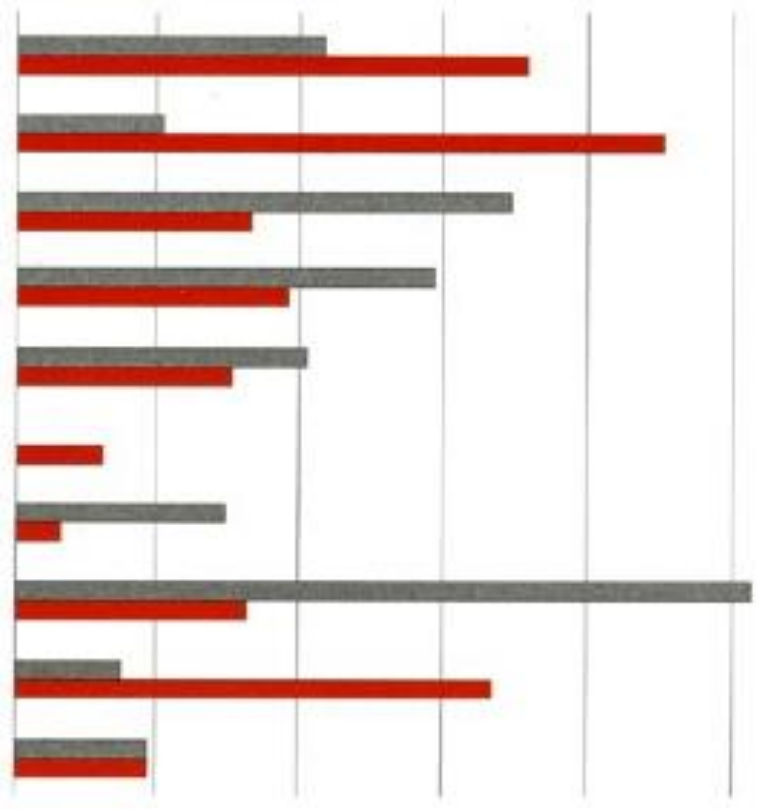

ㅂ. 1992001 . 5 10 15

public-opinion poll: "What are the reasons for moving out?"

\section{Graph 4: Comparison of parameters of 1991 and 2001}

\section{References}

[1] World habitat award 2007 report, vol 1, pp 8-26, January 2007. 
[2] Bundesministerium für Verkehr, Bau- und Wohnungswesen. Dokumentation zum Bundeswettbewerb "Stadtumbau Ost", pp 11-47, (2003).

[3] Cepl, J. Oswald Mathias Ungers's Urban Archipelago for Shrinking Berlin. In P. Oswalt, ShrinkingCities, Volume 1: International Research (pp. 187-195), (2005).

[4] Gruppe Architektur \& Stadtplanung (GRAS).Rahmenplan Südstadt Leinefelde: Aktualisierte Städtebauliche Entwicklungskonzeption. (1999)

[5] Hesse, M, The Compact City: A Model for Eastern German Cities In P. Oswalt, Shrinking Cities,Volume 1: International Research (pp. 180-183), (2005).

[6] Kil, W. "Flaggschiff" des Stadtumbaus. Deutsches Architektenblatt , pp. 26-29, (2007, April)..

[7] Leinefelde. (2005). Rahmenplan Leinefelde-Südstadt. Leinefelde-Worbis: Leinefelde-Worbis.

[8] Reinhardt, G. Stadtumbau Ost - Revitalisierung in Leinefelde. Forum Wohneigentum , pp.135-140, (2003, Heft 3) 